\title{
An Analysis of Factors Influencing the Upsurge of Private Universities in Nigeria
}

\author{
Nelson Ejiro Akpotu ${ }^{1}$ and Williams P. Akpochafo ${ }^{2}$ \\ 1. Department of Educational Administration and Policy Studies, \\ Delta State University, Abraka, Nigeria \\ E-mail: neakpotu@yahoo.com \\ 2. Department of Social Science Education, Delta State University, Abraka, Nigeria
}

KEYWORDS Deregulated education. Demand for Education. Education Participation Rate. Investment in Education. Upsurge. Private Universities

\begin{abstract}
The paper ex-rayed the concept of privatization of education in an era of globalization and massive demand for education. It traced the history of university education in Nigeria, characterized by regulations and as a public good solely funded by government until the dawn of the $21^{\text {st }}$ century. In an attempt to justify the upsurge of private universities in Nigeria, the paper examined the trend globally, and succinctly advanced reasons for the establishment and growth of private universities for standards and quality; increased access and better funding to meet the needs of globalization and the deregulation of hitherto publicly managed organizations .
\end{abstract}

\section{INTRODUCTION}

The debate for privatization of education has become a global issue in recent years. The debate has come in different forms with different interpretations such as deregulation; increasing the role of parents in the financing of education (Belfied and Levin 2003); private ownership of the funding and management of schools and the private investment with focus on cost recovery (Ndebbio 1983; Psacharopolous and Woodhall 1997; and Olaniyan 2001). The heavy burden of ever-increasing government expenditure on higher education in both developed and developing nations no doubt necessitated the debate. As indicated by Kitaev (2003) private education is a reality and has been growing around the world together with globalization. Even in the centrally planned countries of Eastern Europe, France and the egalitarian Germany; former Soviet Union, China, Mongolia and Tanzania; where the culture of private ownership of educational institutions was alien; the wind of globalization and market reforms have reverted the situation.

From the very beginning when university education commenced in Nigeria in 1948, the government conceived of its nature as a public or social good whose production must not be left in the hands of the private sector. Hence, from then until 1999, a period of over fifty years, the establishment, ownership, management and funding of universities and all tertiary educational institutions remained the exclusive reserve of Federal, Regional and State Governments. Before the 1972 Federal Decree on education and the government take-over of all educational institutions, there were only two Federal universities and four Regional Government owned universities. Then tuition fees were charged; however, with the Federal Decree on education in 1972, the Federal Government took-over all universities and by 1975, abolished tuition fees in all universities (Eze 1983; Olaniyan 2001). The government decision to take-over the universities could only be guaranteed while the problems of equity, access and imbalance continued unabated (Nwadiani 1997; Adeyemi 2001; Okobiah 2002).

Since the Federal Government take-over of universities, she had made different efforts to revert the decision. The 1979 constitution, which listed education on the concurrent legislative list, saw the birth of State universities. The number of State owned universities has increased to twenty-two as against twenty-six Federal (NUC 2004). The fact remains that the supply of university education in Nigeria has always been limited by the amount of funds that the owners (governments) have been willing and capable of giving to the universities as grants. The Nigerian Government, which hitherto denied states and private ownership of universities, has come to acknowledge the obvious reality.

The year 1999 marked the rebirth of private universities in Nigeria with the establishment of 
Babcock, Igbinedion and Madonna universities. Since then there has been tremendous increase in growth of private universities. For instance, while there were seven private universities at the close of 2003/2004 academic session, Babcock, Igbinedion, Madonna, Pan African, Benson Idahosa, Bowen and Covenant, the number had increased to sixteen; more than doubled by the close of 2004 .In fact, additional eight private universities will be established before the end of 2005 (NUC 2005). Thus, by the close of the year 2005 , there will be twenty-four private universities in Nigeria. This implies a growth rate of six private universities per annum (19992005). By this unprecedented rate, the number of private universities would have almost equaled the twenty-six Federal universities and exceeded the number of State owned (22). Indeed, indications are that the number will rise to thirty by the end of 2007 (NUC 2005).

This paper therefore, attempts to examine the factors that have necessitated the birth of private universities in Nigeria; while suggesting the role of Government in ensuring the realization of the goals of university education and ensure an enhanced policy of private participation.

\section{Factors Responsible for the Growth of Private Universities in Nigeria}

For the past four years, since the beginning of the twenty-first century, the Nigerian university system has been going through radical transformation and reforms. These reforms, according to Imoke (2005), and (NUC 2005) are geared towards expanding access, promoting and ensuring quality and increasing institutional efficiency and thereby be responsive and relevant towards the production of qualitative, globally competitive entrepreneurial and selfreliant graduates. This, among others could be responsible for the Federal Government sudden change of attitude towards granting of license to private universities in Nigeria as the National Universities Commission (NUC) represents in part, the voice of government.

\section{Global Trend in Private Ownership of Educational Institutions}

There has been a global trend in private proprietorship of educational institutions over the years even in socialist countries like Tanzania and in the former Soviet Union, Eastern Europe; the "for profit schools" in India; Trinidad; Tobago; Ghana and Mongolia. (International Institute for Educational Planning, IIEP, 2000; 2003). As the IIEP (2003) remarked, private education is a reality and its impact is growing around the world together with globalization, in particular at non-compulsory levels-preschool, tertiary and postgraduate. In Colombia, the private sector has been most responsive to the increased demand for tertiary education with almost 67 percent of total enrolment and 40 percent of enrolment in evening and night courses. This appears to be the trend in most Latin American countries and the Caribbean. Teather (2004) also lending support to this claim, agued that a variety of important and intensified socio- cultural, economic and political developments including globalization, privatization and an increasing presence of market dynamics have been affecting higher education operations the world over.

According to Lai-ngok (2004) China, although a one-party ruling system; the state has deliberately retreated from its role as a welfare service provider and has been gradually transferring the responsibility of providing educational services to the local level, the community level or even to individuals through the notions of decentralization and "marketization". As most other countries involved in privatization, China's chief motive for decentralization of her educational system is finance. The financial straits of the central government to provide adequate educational funding for the entire country has been very burdensome and therefore; transferring the fiscal burden from the central government to local governments, communities, individuals (Lai-ngok 2004) and the private sector became the plausible solution to extricate the whole system from its plight

Indeed, private educational institutions exist, parallel with government institutions at all levels in most developed and, in recent times developing countries. In Australia, they have always played substantial role in the Australian educational development. For example, since 1998, private educational institutions have enrolled no less than 30 percent of all school students. In addition, in Colombia, the private sector has been most responsive to the increased demand for tertiary education, accounting for almost 67 percent of total enrolment (Canada National 
Library Report, 2001). In Belgium, private schools account for 60 percent of enrolment in all schools. Also, in Spain, private schools enroll 30 percent of all enrollee, while it accounts for 25 percent in France.

In Nigeria, the trend has been that of the private sector gradually taking over the primary and secondary sub-sectors of the education industry. In most parts of South-West, SouthEast and South-South of the country, the number of privately owned pre-primary, primary and postprimary educational institutions have grown exceedingly and their enrolment figures have far exceeded enrolment in public schools. In the Nigerian context, proprietorship of schools has become a big business. According to Alli (2004), private school system is one of the most profitable sectors of the sluggish Nigerian economy, readily attracting huge investment from banks, foreign investors and wealthy Nigerians. Those wealthy investors who have tasted the profitability at the lower level desire to establish private universities. In Kenya, there has been dramatic rise in the number of private universities; which has risen from three in the 1980's to seventeen in 2004. Moreover, the number of private universities is three times the number of public universities (The East African Standard, May 2004).

\section{The Failures of the Public Institutions}

The establishment of private schools is no doubt a response to the failings of the public school system. In Nigeria today, people strive to provide boreholes or water for themselves and generate electricity because the government has failed to meet their expectations. For instance, Alli (2004) observed that Nigerians generally have the peculiar attitude of individual solution as a response to social malaise. With increasing awareness of the importance of education for human emancipation and development, Nigerians continue to adopt the usual and peculiar response, which is the private option. No doubt, public organizations and the universities alike have remarkably been unable to respond to the challenges of service excellence; resulting to poor performance. In the past decades, there have been crises of different types and intensity. Of all the crises, that of scarce resources arising from under-funding has been central. Resources for university education in terms of staff need, funds, physical facilities and equipment have conti- nuously been in state of acute shortage in Nigeria (Nwadiani 1993; Utulu 2001; Nwadiani and Akpotu 2002; Akpotu and Nwadiani 2003; NUC 2005).

Resource required to provide qualitative education has been scarce, while students' desire for university education continued to mount. Private sector participation in the provision and management of university education therefore, appear to ensure the production of quality graduates; bearing in mind that Nigeria is reputed to have the most dynamic and daring private sector in Black Africa.

The failure of public tertiary institutions in Nigeria manifests in the form of enlarged teacherstudent ratio; overcrowded classes; poor quality teaching and research; examination malpractice; cultism and incessant strikes of staff (NUC 2005). Akpotu (2004), for example, found that a total of 99.55 weeks (i.e. 3.32 academic years) were lost in Nigeria universities for a period of six years. This represented a cost of \#49,211, 035,332 billion or $\$ 684,198,230.8$ million. The study also showed that a total of 11.4 million man-hours and 28.54 million student - hours were lost during the strikes. Strikes bring about destabilization of the learning process and lead to low quality service from lecturers because of their desire to cover lost ground. All stakeholders in the university system have become disenchanted with the universities and their graduates who are now perceived as half-baked. Consequently, more parents and guardians tend to opt for private universities where strikes and other vices associated with public universities are virtually non-existent. More so, when competition has become the bane of a global world economy.

\section{The Growing Demand for University Education and Absorptive Capacity}

Almost 30 million people in the world are fully qualified to enter a university; but no university place is available for them (Duderstadt 2002). Bearing in mind that no less than half of the world populations are youth under age twenty, most of whom live in Africa, Asia and Latin America, its implications on staggering demand for university education is enormous for government alone to shoulder. In Nigeria for instance, the series of committees set up by the Federal Governments over the years (Longe Commission of 1990; Etsu Nupe Committee on the future of 
Higher Education in Nigeria, 1996; and the Education, Science and Technology Committee of Vision 2010, 1997) consistently reported of the gross inadequate provision of university education in Nigeria (Olaniyan 2001).

In the absence of improved facilities to cope with increased demand many of the universities had to exceed their carrying capacities, which is defined as the maximum number of students that the institution can sustain for qualitative education based on available human and material resources (NUC 2005).

As shown in Table 1, the Federal and State universities exceeded their carrying capacities with 193,557 students. Since the Federal and State universities are adjudged by NUC to exceed their carrying capacity, in the absence of their improvement in facilities, increased enrolment in the private universities may be the immediate solution, more so enrolments in private universities is still relatively very low.

Table 1: Current enrolment and carrying capacity of Nigerian universities

Type of university Current Carrying Difference enrolment capacity

Federal Universities $442,834 \quad 342,049+100,785$

State Universities $265,166 \quad 163,586+101,580$

Private Universities $\quad 19,740 \quad 28,548 \quad-8,808$

\begin{tabular}{llll}
\hline Total & 727,740 & 534,183 & $+193,557$ \\
\hline
\end{tabular}

Source: NUC (2005)

Okebukola (2004) believed that the absorptive capacity of Nigerian universities would sooner get worse. As shown in Table 2, the unsatisfied demand for university education for the period $1978 / 79$ to $1999 / 2000$ revealed that at no time did Nigerian universities, all put together, admit up to twenty-five percent of applicants. Consequently, there has always been a large pool of persons seeking university admission thus raising anxiety, frustration and "wait-time". The gap between demand and supply will get wider if, as shown in Table 1, the Federal and state universities must reduce their admission quota in response to the NUC guideline on absorptive capacity.

Okebukola (2004) based his argument on the fact that by the year 2010, the children of the Universal Basic Education (UBE) enrolled in 1999 when the programme started would begin to exit secondary schools and a minimum of 10 percent will knock the doors of universities for admission. According to him, the total absorptive capacity for fresh admissions of the 55 universities now
Table 2: Extent of unsatisfied demand for university education In Nigeria (1978-2000)

\begin{tabular}{llllc}
\hline $\begin{array}{l}\text { Acade- } \\
\text { mic }\end{array}$ & $\begin{array}{l}\text { Number } \\
\text { of } \\
\text { year }\end{array}$ & $\begin{array}{l}\text { Number } \\
\text { admitted }\end{array}$ & $\begin{array}{l}\text { Percen- } \\
\text { tage } \\
\text { admitted }\end{array}$ & $\begin{array}{l}\text { Un- } \\
\text { satisfied } \\
\text { DD }(\%)\end{array}$ \\
\hline $1978 / 79$ & 114,801 & 14,417 & 12.6 & 87.4 \\
1980 & 144,939 & 28,213 & 19.5 & 80.7 \\
1981 & 180,673 & 26,808 & 14.8 & 85.2 \\
1982 & 205,112 & 29,800 & 14.5 & 85.5 \\
1983 & 191,583 & 27,378 & 14.3 & 85.7 \\
$1984 / 85$ & 201,140 & 27,482 & 13.7 & 86.3 \\
$1985 / 86$ & 212,114 & 30,996 & 14.6 & 85.4 \\
$1986 / 87$ & 193,774 & 39,915 & 20.6 & 79.4 \\
$1987 / 88$ & 210,525 & 36,356 & 17.3 & 82.7 \\
$1988 / 89$ & 190,353 & 41,700 & 21.9 & 78.1 \\
$1989 / 90$ & 255,638 & 38,431 & 15.0 & 85.0 \\
$1990 / 91$ & 287,572 & 48,504 & 16.9 & 83.1 \\
$1991 / 92$ & 398,270 & 61,479 & 15.4 & 84.6 \\
$1992 / 93$ & 357,950 & 57,685 & 16.1 & 83.9 \\
$1993 / 94$ & 420,681 & 59,378 & 14.1 & 85.9 \\
$1994 / 95$ & - & - & - & - \\
$1995 / 96$ & 512,797 & 37,498 & 7.3 & 92.7 \\
$1996 / 97$ & 475,923 & 79,904 & 16.8 & 83.2 \\
$1997 / 98$ & 419,807 & 72,791 & 17.3 & 82.7 \\
$1998 / 99$ & 340,117 & 78,550 & 23.1 & 76.9 \\
$1999 / 2000$ & 417,773 & 78,550 & 18.8 & 81.2 \\
\hline
\end{tabular}

Sources: JAMB, 1988, 1999, 2001

is about 160,000 . If 6.3 million eligible candidates come knocking about five years from now, the existing universities can admit only about 160,000 (or 0.16 million), which is 2.4 percent. To reduce frustration and the "wait-time" for the over 97 percent of those that would exit secondary education in 2010 more universities are required and the upsurge of private universities would partly remedy the situation by absorbing part of those candidates that would be denied admission in public universities.

\section{Need to Increase University Education Participation Rate (UEPR)}

The UNESCO Education World Reports of 2001 to 2004 indicated that university education participation rate (UEPR) for fast developing countries ranges from 25 percent to 45 percent. The indication is that for rapid development and improved human capital development at least 2545 percent of a nation's population aged 18 to 30 should be enrolled in universities. To achieve this target, the licensing of private universities in Nigeria is targeted at helping to ensure that by the year 2015, a minimum of 30 percent university education participation rate would be achieved (NUC 2005). America for example, has been able to achieve almost 100 percent Gross Enrolment 
Ratio (GER) (IIEP 2003) while Nigeria is only able to achieve about $5 \%$ (Teferra 2003). This can be attributed among others, to the many private colleges and universities, and the diverse forms of tertiary educational institutions in America.

Consequently, some well-meaning Nigerians have called for more universities. Abubakar (2004) argued that Nigeria needs 70 more universities in the next six years. For example, some countries with less population than Nigeria boast of more universities. Argentina with 38.7 million people has 1,705 universities; Spain with 40.2 million has 145; Mexico with 10.9million has 1,341 and France with 60.1million has 1,062 universities (Ababakar 2004). With dwindling resources, it is obvious that only the establishment of private universities can increase Nigeria's UEPR. Some African countries are already responding to the pressure on them for increased university education participation rate. Taferra and Altbach (2003) gave the number of private higher education institutions in some African countries as follows: Kenya 13; Sudan 22; Democratic Republic of Congo 260; Ghana 11; Uganda 10; Togo 22; Ethiopia 20; and Madagascar 16. Nigeria cannot be an exception in the worldwide push to increase UEPR, more so she has the largest population and enhanced natural and human resources for sustenance.

\section{As a Means of Reducing the Burden of Education on Government}

Funding issues loom very large when considering African higher education. Financial constraint is one of the major problems facing Nigeria universities. Financial crisis of the universities arise from economic recession in the country, which emanated from the heavy dependence on oil as a major source of revenue. Much as the federal government has been struggling to increase statutory allocations to the universities, these subventions have continued to be insufficient to cope with the increasing enrolment and the increasing contending alternative users of the government scarce resources. In fact, there has been the consensus that demand for higher education has been growing faster than the willingness of government to supply it, more so, every one wants government to increase spending on education, while resisting individual payment for it (Olaniyan 2001).

Indeed, as shown in Table3 the federal
Table 3: Education as a percentage of federal government expenditure 1992 to 2004

\begin{tabular}{lc}
\hline Year & Allocation to education as \% of total budget \\
\hline 1992 & 6.3 \\
1993 & 7.3 \\
1994 & 14.9 \\
1995 & 13.0 \\
1996 & 10.8 \\
1997 & 11.6 \\
1998 & 10.3 \\
1999 & 11.12 \\
2000 & 8.36 \\
2001 & 7.0 \\
2002 & 5.9 \\
2003 & 1.83 \\
2004 & 10.5 \\
\hline
\end{tabular}

Source: ASUU Bulletin December 2002

government spent merely between $1.83 \%$ in 2003 and $14.9 \%$ in 1994 of her total expenditure on education. The percentage expenditure even declined consistently from 1999 when the present civilian government came into power until 2004 when it rose again to $10.5 \%$. Even with the reduced budgetary allocation to education, university education continued to consume, on the average $51.7 \%$ of the total allocation to education. (Olaniyan 2001). Thus, in spite of the fact that there are only twenty-six federal universities, she consumes more than half of the total share of education, there by denying other sub sectors of the education system their fair share. .Consequently, the federal government is too willing to divest itself of the heavy burden of education by encouraging private sector participation, which has become a global phenomenon. Indeed, it is an obvious situation of dire need which has created opportunity for government to deliberately grant licenses to individuals and groups to establish private universities so as to create more access for the teeming Nigerians seeking admissions into the already over crowded universities. Of crucial significance is the fact that among African nations, Nigeria appears to spend the least proportion of her GNP on education. While Nigeria spends about $0.76 \%$ of her GNP on education, South Africa spends 7.9\%; Kenya 6.5\%; Malawi 5.4\%; Cote d' Ivoria $5 \%$; Angola $4.9 \%$; Ghana $4.4 \%$ and Tanzania $3.4 \%$. (Dike 2005).

\section{The Demand for Foreign Universities}

Many Nigerian parents, who could afford, send their children to foreign countries for 
university education. Nevertheless, imagine the difficulties that such prospective students and their parents encounter seeking student visa. For example, Alli (2004) remarked that at a time, Ghanaian authorities had to put a ceiling on the number of Nigerians that could be admitted into their universities because of the large number of Nigerians seeking admission into Ghanaian universities. In addition, although data are not readily available, the number of Nigerians besieging the British or American embassies and consular offices seeking student visa to Britain, Canada and the US on a weekly basis can be terrifying. For example, (Gozney 2007) indicated that Nigeria has the fifth largest population of students studying in the United Kingdom. Sir Richard Gozney, the British High Commissioner in Nigeria indicated that in 2006 alone, 27,000 Nigerians applied for students' visa of which $75 \%$ of them were refused. This portrays a situation where many Nigerian students are refused admission into universities, both within and outside the country due to limited supply. This development has been a crucial and perennial problem of concern to governments. As (Osuji, 2003) indicated governments in Nigeria have been trying to reverse the present trend whereby parents now prefer to send their children to Ghana, South Africa, Gambia, Uganda, Canada, Europe and America. In the circumstance, the establishment of private universities with comparable international standards becomes the most feasible alternative to help reduce the trend, which is prone to worsening the brain drain and capital fright phenomenon.

\section{Ownership of Universities as an Investment}

Education has come to be universally accepted as an investment good. Blaug (1980) rightly acclaimed that education is a profitable private investment and higher earnings of educated people is significant element in the demand for education. He then advised that it might be fruitful to look at the demand for education and training as an investment demand to prospective lifetime earnings. Education is not only an investment to the individual and his family, but also to the governments, corporate bodies and institutions or entrepreneurs. Hence, just as the amount of education an individual possesses positively correlates with his lifetime earnings, so is the level of economic growth and development. The realization of this investment dimension of education, no doubt has necessitated the increasing desire of private educational entrepreneurs in all levels of the educational system. Hence, even as there has not been remarkable growth in most sectors of the Nigerian economy, the growth in the private provision of educational institutions has been alarming. Today most proprietors appear to see the educational sector as the quickest and safest means to receive quick returns on investment with minimal risks, as there are always students to admit in a youthful populated country as Nigeria. In the same vein, the government has come to realize the huge benefits of education to the individual as well; and is therefore beginning to look at plausible avenues to share the responsibilities most fairly, without offending students or parents who have been opposed to fees in universities. Thus, the upsurge of private universities in Nigeria is a child of circumstances that has gradually established the long neglected need for diversified funding alternatives for education. In addition, the private sector in Nigeria and most African states contribute very minimally to funding education (Olaniyan 2001); yet complain of poor quality graduates. Hence, their direct involvement would cause the actualization of the investment dimension.

\section{CONCLUSION}

The operation of university education in Nigeria has been confronted with numerous problems that threaten the realization of its vision and mission. In the modern age of information and technological progress and globalization, the society expects the university to be more dynamic and responsive to changing and competitive world economy. Also, in this era of massive demand for education, which governments find difficult to solely fund, promoting, stimulating and motivating the participation of the private sector in developing and investing in education can be highly rewarding. Indeed, private sector participation in the provision and ownership of universities would ensure the production of quality graduates and enjoy a closer contact between the private universities and the industries and so, will ensure that the universities are more relevant to the needs of society. For education to serve truly as the primary agent for achieving sustainable development, democrati- 
zation, liberalization, decentralization and privatization must be taken as essential policy precursors for improvement of standards and quality.

No doubt, private universities like Harvard in the developed world represent vibrant growing institutions of higher education providers. As a way of ensuring, that standards and quality are maintained, sustainable and enduring policies for quality control and monitoring must be set up with well-defined parameters that meet with international standards; while at the same time ensuring increased access.

\section{REFERENCES}

Abubakar M 2004. Why Nigeria needs 70 Universities in six years by Okebukola. The Guardian, Tuesday August 19, 2004, pp. 49-51.

Adeyemi K 2001. Equity of Access and Catchment area factor in University Admissions in Nigeria. Higher Education, 42: 307-332.

Akerele WO 2001. Managing Nigeria's Higher Education in the $21^{\text {st }}$ Century. Proceeding of the $12^{\text {th }}$ General Assembly of the Social Science Academy of Nigeria $(S S A N)$ : pp. 190-198.

Akpotu NE, Nwadiani M 2003. Factors Influencing Academic Staff Turnover in Nigerian Universities. Higher Education Review, 36 (1): 45-56.

Akpotu NE 2004. Analysis of the Cost of National Strikes in Nigerian Universities (1992-2003). Higher Education Review, 37(1): 49-58.

Belfied CR, Levin HM 2003. Educational privatization: Causes, Consequences and Planning Implications. International Institute for Educational Planning (IIEP)/ Paris: Unesco.

Blaug M 1980. An Introduction to the Economics of Education. NY, England: Penguin Books Ltd. Colombia and private sector participation in tertiary education. 2001.Canada National Library Report. http://www.worldbank.org/tertiared/canada. htm

Dike V 2005. The State of Education in Nigeria and the Health of the nation http://www.afbis.com/analysis/ education 10204234737.htm 6/21/2005.

Duderstadt JJ 2002. The Future of Higher Education in the Knowledge-driven Global Economy of the $21^{\text {st }}$ century. 175 th Anniversary Symposium of University of Toronto, Toronto, Canada.

Eze A 1983. Economics of Education- The Nigerian Experience. Owerri: New Africa Publishing Co. Ltd.

Gozney R 2007. Nigerian Students $5^{\text {th }}$ largest in UK. Vanguard, Thursday, June 28, 2007, P. 14

International Institute for Educational Planning Newsletter (IIEP) 2000. XVIII (2) April - June 2000, pp. 5-10.

International Institute for Educational Planning Newsletter (IIEP) 2003. XXI (1) January - March, 2003. pp. $5,7,10$.
International Institute for Educational Planning Newsletter (IIEP). 2003. XXI (4) October - December 2003. pp. 9-11.

Joint Admission and Matriculation Board (JAMB) 1988 , 1999, 2001. Statistical Digests Web Site: www. jambng.com

Kitaev I 2003. Higher Education in the Baltic States: Between crisis and renewal. IIEP Newsletter, XXI( 1). January-March, 2003, pp. 6-7.

Lai-ngok JW 2004. School Autonomy in China: A comparison between Government and Private schools within the context of Decentralization. Journal of the Commonwealth Council for Educational Administration and Management, 32(3): $58-73$

National Universities Commission (NUC) 2005. Admission Quotas for 2005/2006. Monday Memo, 4(21): 4-6.

Ndebbio JEU 1983. The Rationale for using price systems in determining priorities in higher education in developing African Countries: A suggested policy approach for Nigeria. Nigeria Educational Forum, 6(1): 1-8.

Nwadiani M 1993. Planning Nigeria's Higher Education in the 1990s and Beyond: Rationale and Challenges. Journal of Higher Education, 16(2): 283-292.

Nwadiani M, Akpotu NE 2002. Academic Staff Turnover in Nigerian Universities (1990-1997). Education, 123(2): 305-312.

Okebukola P 2004. The Choice and Balance between Quality and Quantity in the Nigerian University System: Admission Quota for 2005/2006 National Universities Commission." Monday Memo, 4(21): 1-4.

Okobiah OS 2002. The Educational Imbalance between the Northern and Southern states of Nigeria: A redirection of Educational Policies. Inaugural Lecture Series Delta State University, Abraka, March, 2002.

Olaniyan O 2001. Public Finance and Higher Education in Nigeria. Proceedings of the $12^{\text {th }}$ General Assembly of the Social Science Academy of Nigeria (SSAN) pp. 101-119.

Opatola A 2001. Management of Higher Education in Nigeria in the $21^{\text {st }}$ Century: Issues and Challenges. Proceedings of the $12^{\text {th }}$ General Assembly by SSAN. pp. 199-205.

Psacharopoulos G, Woodhall M 1997 Education for Development: An Analysis of Investment Choices. New York: Oxford University Press.

Teather D (Ed.) 2004. Consortia: International Networking Alliances of Universities. Melbourne: Melbourne University Press.

Teferra D, Altbach PG 2003. African Higher Education: Challenges for the $21^{\text {st }}$ Century. Higher Education 00:1-30; Netherlands: Kluwer Academic Publishers.

The World Bank Country Study. 2003. Tertiary Education in Colombia. http://www.worldbank.org/ tertiared/canada.htm

Utulu CC 2001. Quality of University Education in Nigeria: Problems and Solutions. Journal of International Studies in Educational Administration and Management, 29(1): 58-66. 